reported one "viewed at close range with binoculars", May 19.

Migrant warblers of this rather inconspicuous type are less easily identified than many showy birds, and the possibility of confusing them with other species, especially in fall plumage, makes it difficult to be certain about the identification of a rare species. In these cases, a specimen record becomes especially important, and adds significance to the previously recorded sight records. It should especially be noted that the specimen had greyish legs, not black as given by Peterson (1947).

According to the A.O.U. Check-list (1957), the Pine Warbler is known to breed in southern Manitoba (Winnipeg, Indian Bay). Salt and Wilk (1958:384) report for Alberta as follows: "The only specimen of the pine warbler taken in Alberta is a male collected at Castor in June, 1924. During the summer of 1928 several pairs of pine warblers were observed near the town of Athabasca. They appeared to have established territories but no direct evidence of nesting was found. There are also sight records of pine warblers at Glenevis and in the Cypress Hills." Could it breed in Saskatchewan? Griscom (Griscom and Sprunt, 1957: 176-177) reports that this species, which is especially adapted to various species of pine trees chiefly in the eastern United States, has been steadily decreasing as a result of clearing of pine forests outside the coastal plain. "Its effort to push north and establish itself in other types of pine woods has not been conspicuously successful." However, L. H. Walkinshaw (in Griscom and Sprunt, loc. cit.) notes for Michigan that the Pine Warbler is found in jack pine, which is the predominant tree throughout the northern portion of the lower peninsula, seeming to prefer stands where the trees are over 25 feet in height. In view of the resemblance of its song to that of the Chipping Sparrow it may well be that we have overlooked a species which may be resident in some parts of Saskatchewan.

\section{LITERATURE CITED}

American Ornithologists' Union. 1957. Checklist of North American birds. 5th edition. Baltimore. $691 \mathrm{pp}$.

Houston, S. 1958. An evaluation of the distribution records for Saskatchewan birds in the revised edition of the A.O.U. Checklist. Blue Jay, 16:44-47.

Houston, C. S., and M. G. Street. 1959. The birds of the Saskatchewan River, Carlton to Cumberland. Sask. Nat. Hist. Soc. Spec. Pub. No. 2, Regina. 205 pp.

Solt, W. R., and A. L. Wilk. 1958. The birds of Alberta. The Queen's Printer, Edmonton. $511 \mathrm{pp}$.

Griscom, L., and A. Sprunt, Jr. 1957. The warblers of North America. Devin-Adair Co., New York. 356 pp.

Peterson, R. T. 1947. A field guide to the birds. Houghton Mifflin Co., Boston. 290 pp.

\title{
Brewer's Sparrow at Regina
}

\section{by Robert W. Nero, Regina}

Strong southwest winds brought a large wave of migrant sparrows to the Regina district in mid-May, reaching peak numbers for Chipping Sparrows (Spizella passerina), and especially Clay-colored Sparrows (Spizella pallida), on the 16th of May, the day of the Regina Annual May Count. At noon on that day, Frank H. Brazier and I stopped for lunch in a small grove of trees surrounding abandoned farm buildings about a quarter of a mile southwest of Condie, a station about six miles northwest of Regina. It was a warm day with a dry wind that led us to seek shade. A large number of Claycolored Sparrows evidently felt the same way, for their buzzy calls were conspicuous in the little grove. As we sat down for lunch we heard two or three melodious notes of an unfamiliar species; we decided that whatever the species, it would likely remain in the grove for the lunch period. About 30 minutes later we searched through the trees and hedge but were unable to find any bird to which we could attribute the melodious notes; however, a short while later, upon sounding the auto horn, I was surprised to hear a song which included the notes we had heard earlier. It seemed to have responded to the horn and a moment later when I made a "shhh-shhh" sound, which I had been using to lure birds into sight, it sang again, quite close at hand and close to the base of some balsam poplar trees. I had a glimpse 
of a sparrow which seemed to look like a Clay-colored Sparrow, and I at once called Frank Brazier to view it. A moment later it responded again to the lure call: it came out and perched about two feet off the ground, threw back its head and sang a loud, clear and melodious song. This was at a disitance of about 10 feet and in clear view of both of us. It then flew from the tree together with another sparrow out into the open field. Though we looked for it we were unable to see anything other than what appeared to be Claycolored Sparrows. We were both impressed with its general resemblance to a Clay-colored Sparrow, and noted that it merely seemed less wellmarked than those which we had been seeing all day. However, its distinctive song-which consisted of three phrases, first a series of short, rasping notes, then a clear warbling, followed by short musical notesleft little doubt that we had seen a Brewer's Sparrow (Spizella breweri).

This drab sparrow with the remarkable voice nests some 140 miles away (or perhaps less) in the extreme southwestern part of the province and it was there that I first encountered it in 1962 . I remember particularly how impressed I was with the close proximity of territories of Brewer's Sparrow and the Clay-colored Sparrow, the difficulty of distinguishing between them, and the great difference in their songs. Salt and Wilk (1958) note that "the males sing a rolling song more beautiful than could be expected from such colorless birds. The song starts out with buzzing sounds like those of the clay-colored sparrow but these give way to pure sweet notes which rival in quality those of the vesper and song sparrows." The same authors also note that on migration "they are occasionally found in trees with chipping and clay-colored sparrows." What was possibly another Brewer's Sparrow was observed in the morning of May 20 in Regina by Mrs. Herbert F. Tempel who reports having heard a fine, musical song coming from bushes in her yard. Two birds, of Clay-colored Sparrow appearance, were seen and it was felt that one of these must have been the source of the song, which fitted the description of Brewer's Sparrow given in Peter. son's Field Guide.

Ordinarily this species is residen in the extreme southwestern part o the province, in the arid short gras. plains region. Earl W. Godfrey (1950 Birds of the Cypress Hills and Flotten Lake regions, Saskatchewan. Nat Mus. Can., Bull. No. 120, Biol. Ser No. 40) found it "not uncommon" or the open plains south and north o: Cypress Hills, and cites records for the Frenchman River at Eastend Cypress Lake, Cummings, Piapot, anc Govenlock. Fred G. Bard record finding it east of Val Marie with : nest with three fresh eggs on June 5 1929 (per. communication). In company with Ralph D. Carson anc Bernard Haysom on May 26-27, 1962 I found Brewer's Sparrow commor along the valley of the Frenchmar Creek to about 30 miles east of $\mathrm{Va}$ Marie, or as far as we travelled. I may well range farther north. Frec Bard's records also include mentior of a specimen taken on May 16, 1922 at Lake Johnstone (now Old Wive: Lake) by C. G. Harrold, who note: that this was the only one seen (Har. rold, C. G., 1933. Notes on the bird: found at Lake Johnston and Las Mountain Lake, Saskatchewan, dur. ing April and May, 1922. Wilson Bul letin, 65:16-26.).

In these dry years the Brewer': Sparrow may be more successful thar usual (no pun intended) and we should look in likely areas of sage brush flats for its possible occurrence The present invasion of Lark Bunt ings, etc., supports the view tha widespread climatological change: have affected the present distributior of certain prairie species. It woulc seem to be a suitable time, too, to look for the return of the Dickcisse (see Belcher, M. 1961. Birds o Regina, Spec. Pub. No. 3, Sask. Nat Hist. Soc., Regina). [In this connection see the note by Mrs. Keith Pator on page 111 , which was received afte this was written.]

ANNUAL MEETING
Soskatchewan Natural History
Society
October 16,17,1964
in
Saskatchewan Museum of
Natural History, Regina

